\title{
都市河川周辺で発生する蚊柱濃度の 時空間挙動の定量観測 QUANTITATIVE ANALYSIS OF DENSITY OF SWARM OF MOSQUITOES BASED ON IN-SITU OBSERVATION IN REVIERSIDE
}

\author{
今野雷 $^{1} \cdot$ 稲垣厚至 $^{2} \cdot$ 神田学 $^{3} \cdot$ 宮本康司 $^{4}$ \\ Rai KONNO, Atsushi INAGAKI, Manabu KANDA and Koji MIYAMOTO
1学生会員 学士 (理学) 東京工業大学 理工学研究科国際開発工学専攻 （†152-8852 東京都目黒区大岡山2-12-1） 2正会員 博士（工学） 東京工業大学 理工学研究科国際開発工学専攻 (同上)
3正会員 工学博士 東京工業大学 理工学研究科国際開発工学専攻 (同上) \\ 4非会員 博士（理学） 東京家政大学 家政学部環境教育学科（广173-8602 東京都板橋区加賀1-18-1）
}

This study focuses on the problem of "mosquito swarm" along urban rivers. Different from general biological methods (capture, counting and photograph), we adopted a fluid dynamical approach to investigate the temporal-spatial distribution of mosquito swarm. First, a novel device composed of multiple laser sheets is developed as a mosquito counter in order to quantify the density of the swarm. Second, filed observations are done in Nomi River by utilizing this laser device as well as the other conventional meteorological observations. The followings are the major results obtained:

(1) Mosquito swarms are apparent only about 1 hours before the sunrise heavily on one-sided (sunlit side) along the river.

(2) The hot-sopt of mosquite swarm seems to exist; the cross sections of urban street perpendicular to the river. The locations were roughly fixed with slight perturbations.

(3) The suitable temperature to make swarm is about $22.5^{\circ} \mathrm{C}$.

Key Words : Swarm of mosquitoes, Laser particle counter, River environment, Quantitative analysis, In situ measurement, chironomid

\section{1. はじめに}

密集住宅街を流れる都市河川には，特有の大気環境問 題が存在する．例えば，東工大大岡山キャンパス脇を流 れる吞川では，大きな出水後にみられる下流域での臭気 の問題，そして，河川軸に沿って発生するユスリカの蚊 柱の問題が大きな懸案事項となっている.これらは，散 歩・自転車による動線軸としてのせっかくの都市河川の 機能を著しく損なうものである，そこで，本論文では， 蚊柱の時空間挙動の把握について, 既存の生物学的手法 とは異なる都市気象学的観点からアプローチすることを 試みる.

本論文では対象地域を吞川（詳しくは後述）としてい るが，その選定理由は，吞川水系において大発生したユ スリカが実際に問題として挙がっていたことにある。ユ スリカは単純に不快害虫として問題になっているだけで はなく, 家先の洗濯物に付着し, 実害を出している.ま た，体長の小さな吞川の占有種は，人間の体内に吸引さ れることも多い. 吞川ではまだ報告はないが，近年の研
究から，飛散したユスリカの死骸を吸い込むことでアレ ルギーの原因となることも指摘されており ${ }^{1)}$, 深刻な社 会問題にもなっている.

これまでの蚊柱の研究から，その生態学的な特徵につ いては多くが明らかにされてきている，しかしながら， その発生・発達機構はそれだけで決まるものではなく, 環境場にも大きく影響を受けることが指摘されている 2),3).これに対し，都市の蚊柱が立つような地上数mの 大気環境場は, 流れ場, 温熱環境場, 物質濃度場, など 全てにおいて非常に複雑であり，その物理過程について は未だ分からないことの方が多い゙，また，近年目覚ま しい発達を遂げる数值解析を駆使しても，そのような地 表面近傍の環境を再現することは困難である。つまり， このような大気環境が蚊柱形成にどのような影響を及ぼ しているのか，明らかにされていない.

そこで本研究では実測に基づき，大気環境場とユスリ カの関係性について検討することを目的とし，そのため に必要なユスリカ個体数の観測手法についても新たに提 案する. 


\section{2. 吞川におけるユスリカについて}

本論文で対象としているのは全て吞川水系に生息する ユスリカで, 種族はフタスジツヤユスリカ(学名: Cricotopus bicinctus)である. 体長は2.5 3.0mm程度, エリ ユスリカ亜科に属する. 比較的污濁の少ない水を好む種 であり, 安定して浄水が流れる吞川の上流部では占有種 となっている．吞川は東京都目黒区，世田谷区，大田区 にまたがる2級河川であり，その流水の $98 \%$ は 1995 年よ り新宿区の東京都下水道局の落合水再生センターから流 されている高度処理水による. 河道形態はコンクリート

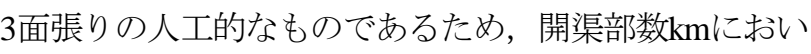
て河道幅は安定して $10 \mathrm{~m}$ 程度である.

また，同じ時期に処理水が流れ込むようになった神田 川でも，この種へと占有種が移行したことが確認されて いる ${ }^{5)}$. 吞川では特に, $10 \mathrm{~cm}$ 程度の低水深のため水中で の天敵が少ないこと，流水が人工処理水のために年間を 通した最低水温が摂氏 $15^{\circ} \mathrm{C}$ 程度であることからユスリカ が大発生している. 温帯に棲むユスリカの最低生育限界 水温は $0.5^{\circ} \mathrm{C} \sim 12^{\circ} \mathrm{C}$ 範囲内と報告されているが ${ }^{5}$, 吞川 では1年中幼虫の生育環境が整っていることになり，実 際に年間を通してその姿を見ることができる.

蚊柱については，諫早湾ではユスリカの蚊柱が大量発 生し，青潮を引き起こすなど大きな社会問題となってい る. これに対し, 蚊柱の物理学的, 生物学的な特性を把 握し, その駆除や, 発生場所の移転などのコントロール することは重要であると考える.

これに対し本研究では, 蚊柱の発生頻度及び濃度につ いて定量的に観測し，これを基に気象学的な側面から蚊 柱の発生特性について検討を行う。

\section{3．吞川における蚊柱発生の定性的な特徵}

2010年秋季に目視による蚊柱の観測調査を行った。そ の目的は，都市河川で発生する蚊柱の定性的な挙動（発 生時刻，発生場所，発生規模など）を把握するためであ る. 観測は東京都目黒区に位置する吞川の開渠区間最上 流部に位置する工大橋から，境橋を経て，島烟橋までの 約500mの区間の河川側道を対象とした（図-1）.

観測手法として，日の入りの時刻から30分間さかのぼ り，10分おきに自転車で周回し，目視で蚊柱を確認した．

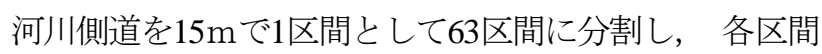
について蚊柱の有無を記録した。観測は9月10日から10 月6日までのあいだ，晴天または曇天日に9日行った。 な お日の入りの時刻は国立天文台天文情報センタ一暦計算 室の情報を利用した.

これにより得られた知見として，都市河川以外でも見 られる一般的な傾向として報告されている，（1）発生時 刻が日没の30分前に現れて日没後にすぐいなくなること，
（2）強風日などは蚊柱が立たないこと，などについては 本対象区域でも同様に見られた。

これに対し，本対象区域特有の現象と考えられる特徵 として挙げられるのは，(1) 河川に突き当たるT字路に 蚊柱が立ちやすい，(2) 河川を囲う高さ2mのフェンス上 に立ちやすい，(3) 降雨後の河川に大きな出水があった 次の日にはほとんど蚊柱は見られない，(4) 下流よりも 上流側（工大橋付近）にて蚊柱が立ちやすい，(5) 河川 の右岸と左岸で蚊柱の発生頻度や規模が異なる，ことな どである.

このうち，(3)の原因としては，大きな出水によりユス リカの幼生が流されることで発生しなくなったことと推 定できる.

また(4)に関して，ユスリカの生物的な特性として，蚊 柱はスワーミングマーカーと呼ばれる地表面の目印にな るようなものを起点に形成されやすいことが知られてい るがの，フェンス上で発生しやすいのはフェンスがス ワーミングマーカーの役割を果たしている可能性も考え られる。しかしながら，地物の違いだけでは上記の (1),(4),(5)のように, 同一地表面条件下での差異を説明す ることはできない.

そこで本研究では, 地物ではなく場の流体力学的, あ るいは気象学的な環境場の違いに着目し, それらと蚊柱 の時空間挙動の変化について検討を行う.また, 先の観 測では定性的な議論に終始していたため, 今回は蚊柱濃 度の時空間挙動を定量的取り扱うための観測を試みた。

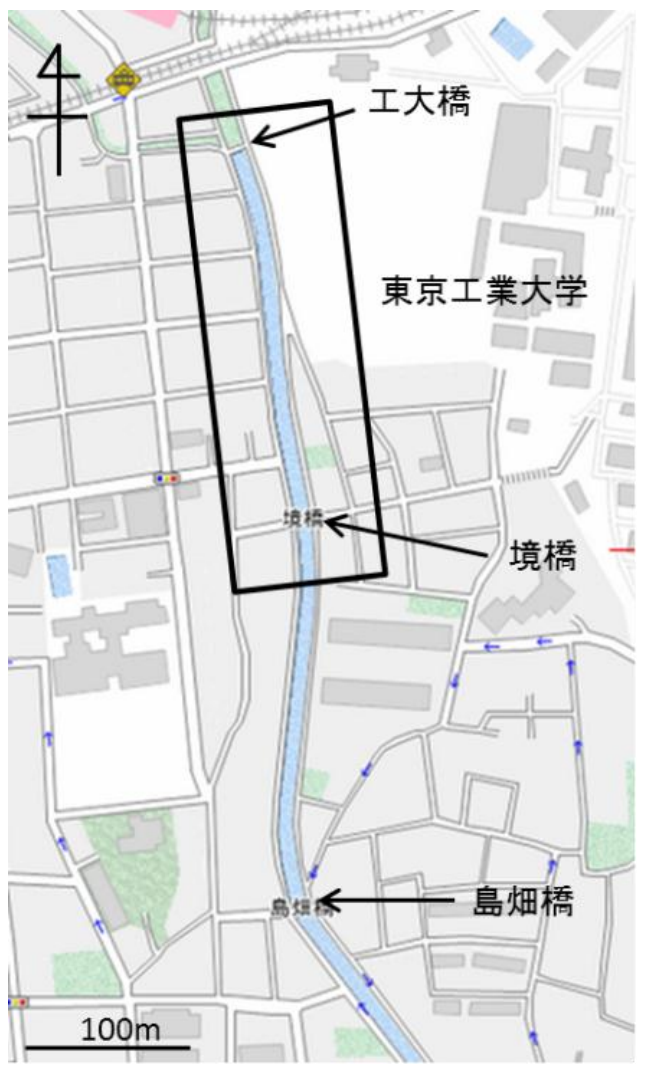

図-1２010年観測領域（枠線内は2011年対象領域） 


\section{4. 観測手法}

\section{（1）レ一ザーを用いた蚊柱濃度の観測手法}

蚊柱の個体数を測定する手法としては，蚊柱の蚊を捕 獲し，その個体数を数える方法がこれまで行われている 1). これらに対し本研究では，数分スケールでの時系列 的な発達及び減衰を捉えることを目的とした，蚊柱に対 する非接触の定量観測手法を提案する．本研究ではレー ザーシートの発受信機を利用し，レーザーシート断面を 横切る蚊の頻度を数えることで，その濃度を定量的に把 握することを試みた.

レーザー発受信機には，KEYENCE社のLV-NH300を センサーとして10台使用した。これは幅 $30 \mathrm{~mm} の$ 線光源 であり，レーザー光のパスを物体が遮ると光の受信強度 が下がることで，送受信機間にある物体を感知すること ができる.さらには受信強度の大小により，30mmの光 源に対する遮蔽幅として, 物体の大きさを推定すること も可能であり，これによって蚊柱の個体数濃度を測定す ることを試みる.

図-2はバリデーションの結果であり，厚さが既知であ るワイヤをレーザーのパス内に入れたときの受信強度の

減少分から求めた測定值と, ワイヤの線径との関係を 表している. この図に示す通り，ワイヤの厚さと受信強 度の関係は線形であり，0.1mmオーダーの物体の測定に も十分耐えうることが分かった。この例を参考に，以後 レーザー光受信強度減衰量をミリメートルの単位に変換 して表記することとする.

ユスリカ単体の受信強度減衰量に関しては，実際に観 測現地で本レーザーを用いた固定点観測を行い取得した。 ビデオカメラと同期させることでユスリカの通過を確認 し，ユスリカが1匹だけ通過する際の受信強度の低下量 を20ケース測定することができた，その結果，20ケース の平均での測定值は $0.66 \mathrm{~mm}$ であった。 ユスリカの平均 的な体長である $2.5 \mathrm{~mm}$ 程度に比べて小さな值が出たのは， 飛行時の姿勢に横向きが多く, 主に体高をとらえている ためと思われる. この観測值を元に，レーザー光受信強 度の低下量とユスリカの個体数への変換を行うこととす る.

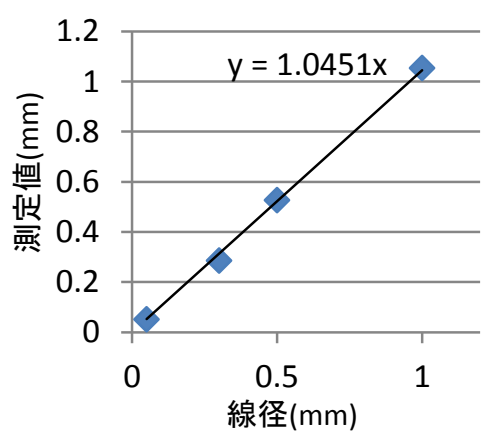

図-2 ワイヤの線径とレ一ザ一光受信強度減衰量から求めた測 定値の関係. 図中の式は線形近似式である.

\section{(2) 計測システム}

先に説明したレーザー送受信機を，アルミ製の台座を 使って内法 $50 \mathrm{~cm}$ 四方の空間に鉛直に配置し，これを自 転車に棒状の支柱で取り付け，進行方向と垂直に測定領 域を設置した（図-3）。電源には測器を携帯できるよう, 鈆畜電池を使用した。この自転車を手で押し測器全体を 移動させることよって，人間の歩行速度で飛行する蚊の 個体数 (濃度) を移動観測することができる.なお，こ のレーザー受信強度はデータロガー（HIOKI 8400）を用 いて $50 \mathrm{~Hz}$ でサンプリングする.

本機器の設置高度として, 先の定性的な観測により蚊 柱はフェンスの上に発生する傾向があるため, 図-4のよ うにフェンスの上を通過できるような高度 $180 \mathrm{~cm} 230 \mathrm{~cm}$ の領域に測器を設置した.

観測項目としてはこの他に，熱電対をレーザー面近傍 に設置して気温も同期した測定を行った。また，位置情 報を得るためビデオカメラを携帯し，周辺の風景の撮影 を同時に行った. また，このビデオカメラでデータロ ガーの電源をオン・オフする瞬間を撮影することで， 1 秒以内の誤差でレーザーのデータとの同期が可能となっ ている.

\section{（3）現地観測}

上記に示した測定器を用いて，吞川周辺で発生する 蚊柱の濃度観測を実施した。観測対象区域は図-1の黒枠 で囲われた箇所であり，先の観測における「上流側」の，

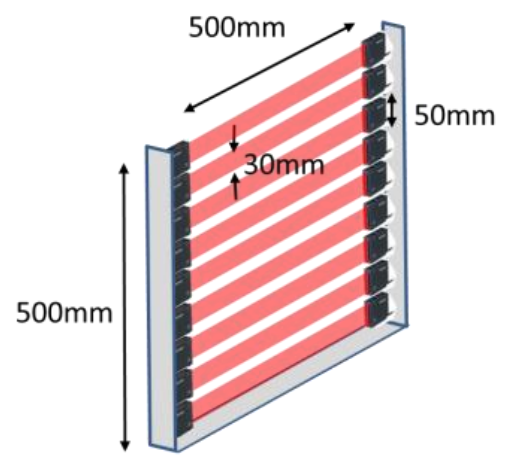

図-3 レーザ一観測機概略図

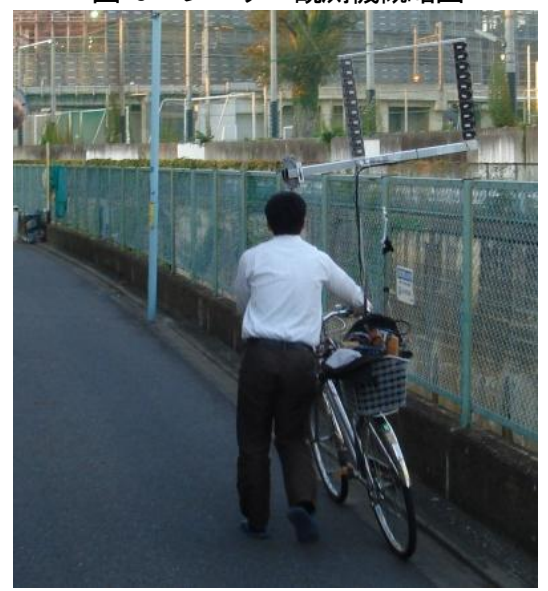

図-4＼cjkstart観測時の様子 
蚊柱が比較的多く発生する区域となっている. 図-5に, この対象区域を拡大した図を示寸。

観測は2011年9月27日に行った。時刻16時53分から17 時33分にかけて, 対象区域内を7周巡回した. 1周の平均 は6分15秒であった．またこの日の日の入り時刻は17時 32分であった.

また，この観測期間中，環境場の基淮点として，東京 工業大学グラウンドにて超音波風速計(Climatec CYG81000)、熱電対により風速と気温をサンプリング周波数 $1 \mathrm{~Hz}$ で測定した(図-5赤丸部分).

さらに追加観測として，同様の条件で上記の実験日よ り連日観測を行った. ただし巡回数は日の入り時刻から 30分前, 20 分前，10分前を開始時刻とする1日3回とした. 位置情報の取得には前述のロガーに接続した電気スイッ チを使い，各区間の境目で信号を送ることにより，ビデ オカメラによる方式よりも精度を増した。 また観測時刻 に雨天であった場合は欠測とした。これにより9月27日 から10月28日までの期間で27日分のデータが得られた. なお10月17日に超音波風速計の故障があったため, 以後 風速風向については10月16日までのデータを利用する.

\section{（4）データ解析概要}

本観測で得られるデータはレーザー受信強度低下量の 時系列変化であり，これを同期していたビデオカメラ画 像から空間情報へ変換する。また考察の際には，観測区 間を図-5に示寸ように東西で32区間（1区間約 $15 \mathrm{~m} ） に$ 分割し, 各地点のユスリカ濃度の時空間変化について検 討を行う。ところで，観測されたデータはユスリカ濃度 と同時に観測時の振動に起因したノイズが含まれる.し かしながら，通常走行時に受けるノイズレベルはユスリ 力通過時に比べ十分低いため, ユスリカ単体の減衰量を 参照し， $0.4 \mathrm{~mm}$ 以下の出力を破棄した. また, 段差の通 過や障害物一の衝突による比較的大きなノイズも，ビデ 才映像を参考に除去することができた.

\section{5. 結果}

\section{（1）時系列特性}

図-6は7回の巡回による観測值を時系列でプロットした ものである. 図中黒線は 1 周の観測值の積算を表してい る。気温は下がってきているが（図-7）,時間が経つに つれて蚊柱は増加し，日の入り 25 分前にピークを迎える ことが分かった. 日の入り直後の7周目にはほぼ観測さ れなかった. 図中青線は東側側道，赤線は西側側道の值 である． 3 周目では東側が低下，西側が上昇をしている が，その後どちらも減少傾向を示している．また，この 時の風向風速はほぼ一定で風の場は安定していた（図一 8).

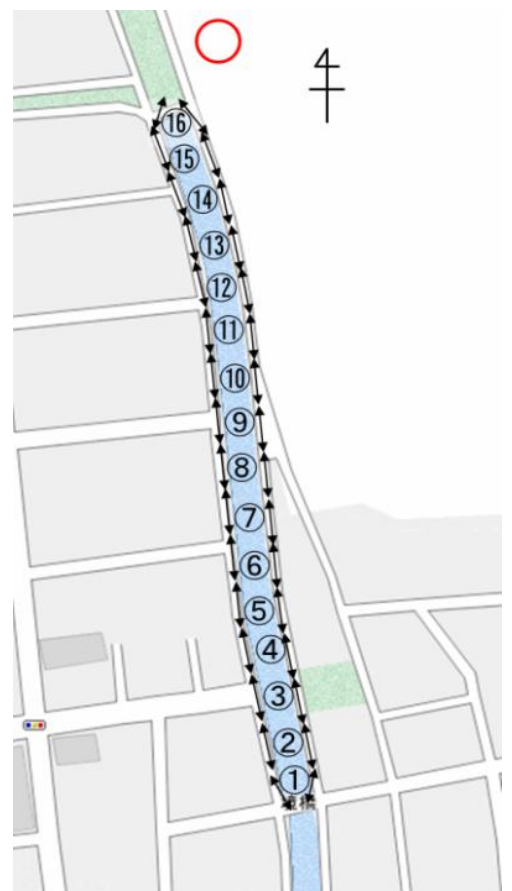

図-5 2011年観測領域

図中の赤丸は風速と気温の定点観測地点を示し， 番号は測定区間を示す.

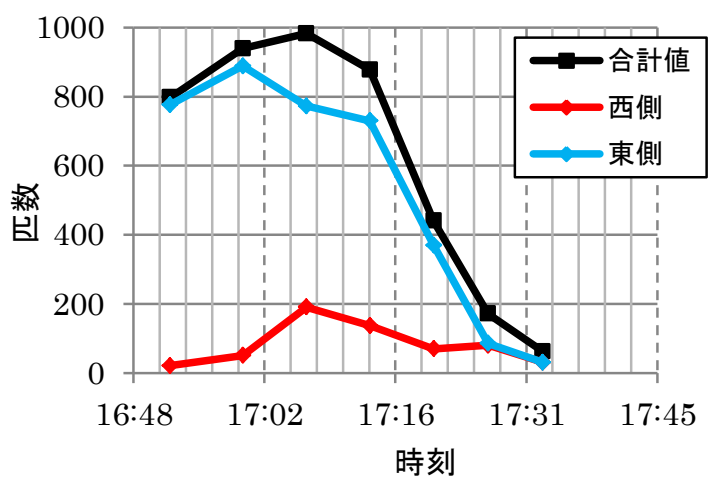

図-6 ユスリカ出現量の時系列変化 黒線:全観測値，赤線:東側，青線:西側

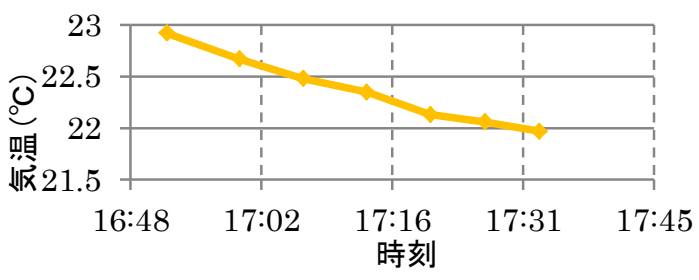

図-7 基準点気温

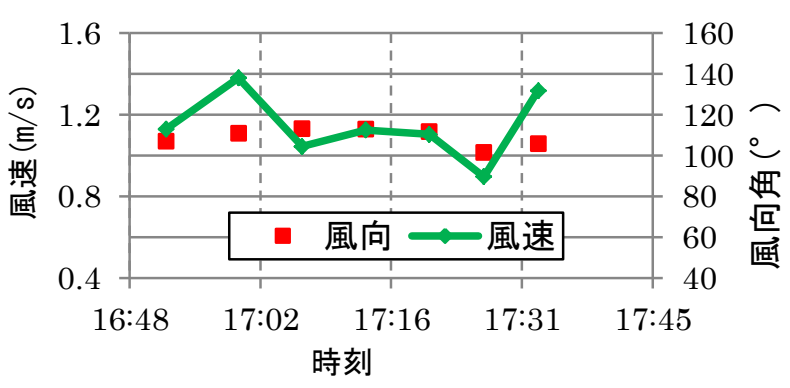

図-8 基準点風向風速 


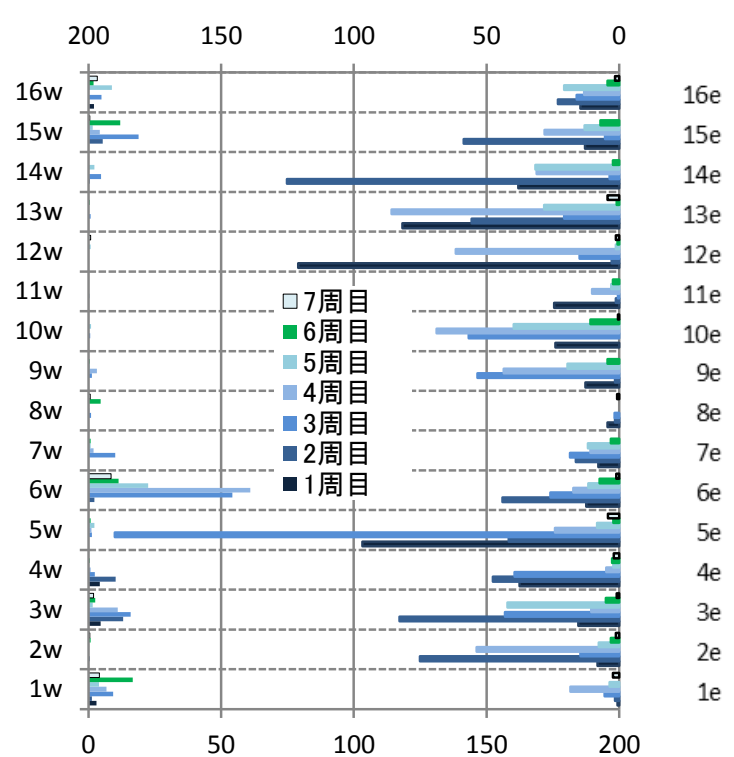

図-9 空間分布(縦軸は区間名，横軸は匹数)

\section{（2）空間分布特性}

吞川上流部における蚊柱の空間分布について検討した。 図-9は各周回の観測量を区間ごとに示したものである. 16区間に対して，西側にw，東側にeという添え字を付 けるものとする.

図-9より，東側では周回ごとに高濃度の区間が変化し ていることが分かる．また西側にも周回によって分布が 見られる.これらのことから，6分間程度の時間間隔で は河川方向に関わらず2区間 $(30 \mathrm{~m})$ 程度の規模で分布の変 化があることが分かる．以下区間ごとに考察していく．

西側では区間(1)w，(3)w，(6)wに小規模ながらも高頻 度で分布が見られた。この区間は西側の交差点または丁 字路にあたる地点で, 西日による日射が差し込む地点と なっている. 区間(8)wから(14)wにかけても丁字路は存在 寸るが，蚊柱の高濃度での分布は見られなかった。

この日の全観測值のうち，西側においては，丁字路が 存在する 6 区間の積算匹数は 271 匹，それ以外の 10 区 間の積算匹数は 112 匹となり（小数点以下四捨五入）, 蚊柱の発生と街区条件は強く関連していると言える．特 に都市においては，緑地，道路，建物といった様々な外 部条件により, 局地的な気象条件の差異が大きくなる. 吞川の西側においても，日射を妨げる原因となる高い建 物が川沿いに存在していることから，このような分布の 差が出たものと思われる (図一10).

区間(16e⿻から (9)eには大規模な分布が多く見られた。こ の区域は植生が多く見られる区域である.さらにこの区 域の中でも区間(14)e，(12)，(10e，(9e)のように，対岸に丁 字路のある区間では周囲の区間よりも蚊柱が集中してい た.

区間(7emら (1)eにかけては，特に前半の周回で大規模 な分布が見られた。この区間は西側に川と低い住宅群が 広がっており，日射の妨げはあまりない，ここでも蚊柱 発生に対する日射の影響の可能性を指摘できる.

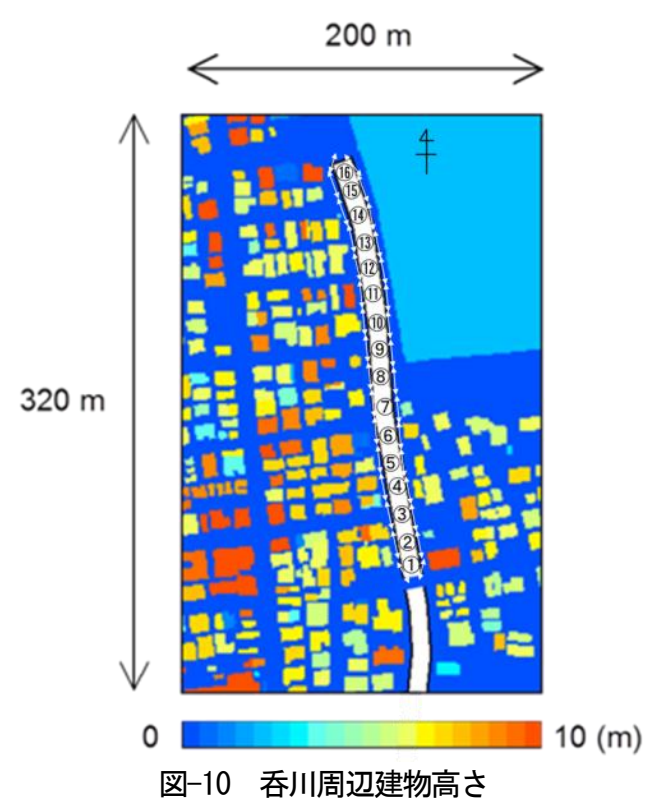

\section{（3）気象場に関する考察}

ユスリカの分布と気象場の関係性について考察した. 連続観測より得られた 27 日分のデータを 1 日ごとに平均 し，さらに東西の観測值に分割したものと気温を示す (図-11)。ただし9月27日は他の日の観測時刻に対応する3 周分のみを利用した．観測されたユスリカの量は緩やか に減少しながらも1日から2日の周期で振動し, 東西の分 布の偏りも一定の傾向を示すことはなかった。これらは 気温の低下による季節影響やユスリカのライフサイクル に関連していると思われる．図-12は各日各周回につい て，レーザー測器近傍の平均気温との関係性を示したも のである. その結果, 摂氏22度から 23 度にかけて, 分布 の集中と大きな観測值（蚊柱）が確認された。 また気温 の低いときにはユスリカは多く観測されなかった.

次に風の場に関連して考察する. 図-13は各日各周回 のユスリカ観測量と, 対応する時刻の風速の相関図であ る. 全体的な傾向として, 風速の小さな時に高濃度の蚊 柱が観測された. 風速 $1.25 \mathrm{~m} / \mathrm{s}$ 前後で大きな観測值が見 られるが，これは9月27日や10月9日といった日にあたり， ユスリカの絶対数が多く, 場全体にあふれていたことが 原因として考えられる. また，いずれの日に関しても観 測時刻(夕方)の風はおおむ称南よりであったため, 風向 に関連したユスリカ分布の東西への顕著な偏りは見られ なかった(図-14).ここでは風向とユスリカの東西分布関 係については議論しないものとする.

ここからはさらに1日の微気象場の違いについて検討 する．図-15は9月27日の全周回のユスリカの観測值と気 温の関係を区間ごとにプロットしたものである.また図 -16はその際の各温度帯のヒストグラムである。 これら より，ユスリカは22.5度付近で大きな観測值が確認でき るが，気温データそのものの分布には大きな偏りがある とはいえない.このことから，ユスリカには飛翔の適温 帯が存在しているものと考えられる. 


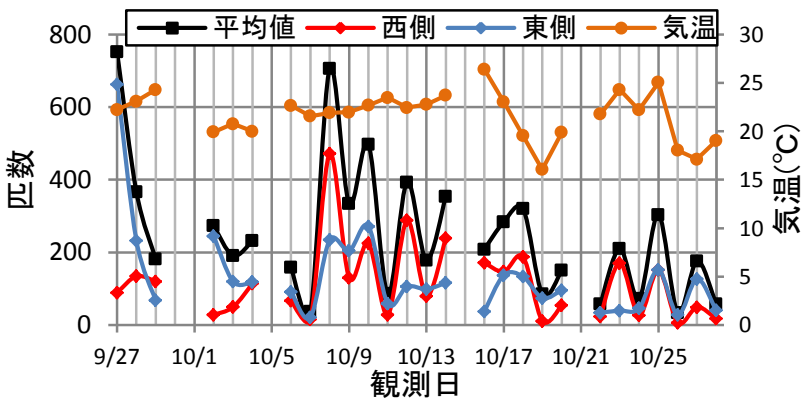

図-11＼cjkstart連続観測のユスリカ観測値と東西の内訳，気温

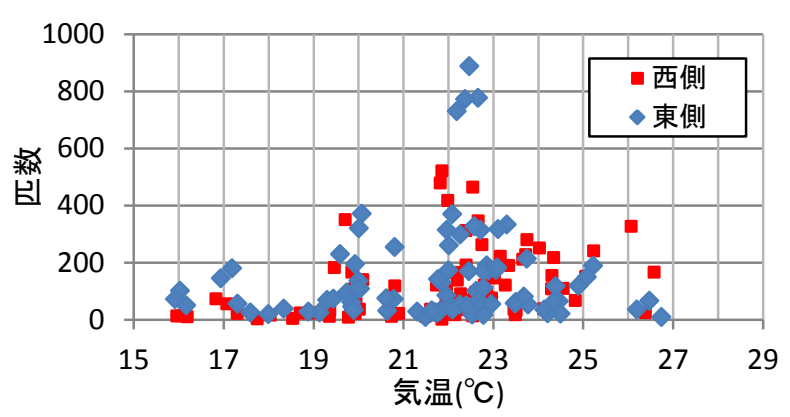

図-12 各日各周回における東西ユスリカ観測値と気温の関係

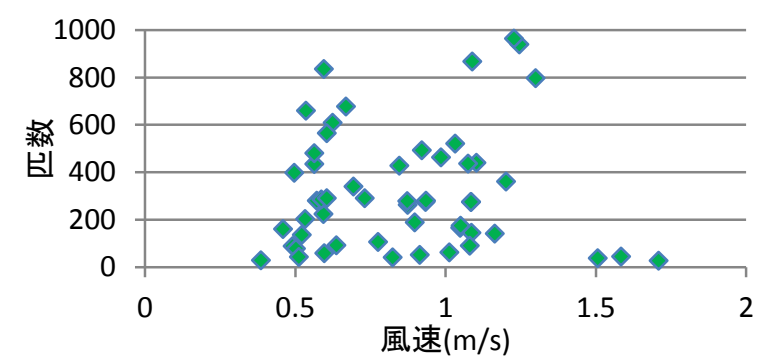

図-13 各日各周回のユスリカ観測値と風速の関係

\section{6. 結論}

本研究では蚊柱の濃度を定量的に観測する手法を開発 し，それを使用して蚊柱濃度の時系列変化及び，発生場 所と気象場の関連性について検討を行った. 以下が得ら れた知見である.

（1）蚊柱の出現は日の入り 25 分前にピークを迎え，その 後日の入りに近づくにつれ姿を消すことが分かった

(2) 蚊柱は主にT字路に発生しやすい.

(3) 今回の観測領域，期間に関しては，ユスリカが蚊柱 をつくるための飛翔条件として， $22.5^{\circ} \mathrm{C}$ 前後が適温 帯として存在することが確認できた.

本論で得られた知見は先の観測で定性的に知られたも のであるが，それを定量的に把握した点に面目がある.

また，従来の手法に比べ，非接触での観測を可能にす ることから，蚊柱の短時間（数分）での動態や増減を捉 えるのに利点がある、今後，本手法を利用することで新 たな知見が得られる可能性を有している.

(4) 今後の展望

日照条件と 1 区間スケールの分布の関連性を議論する ためには，時空間解像度の高い日射データが必要となる. 複数の放射計による区間別の観測や図-10のような建物 情報を基にした詳細な数值計算による情報の取得が有効 である。 また観測時間内でのユスリカの休息，再飛翔，

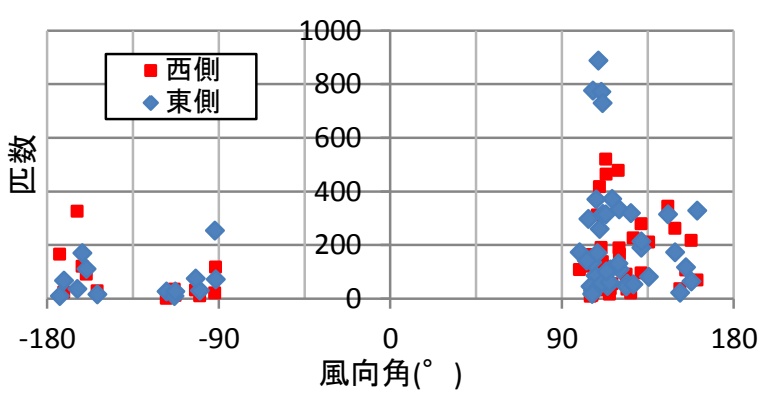

図-14＼cjkstart観測時の風向に対するユスリカ観測値の分布

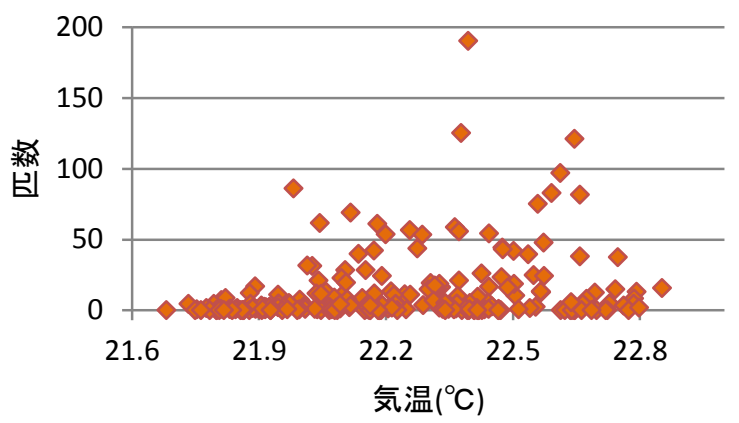

図-15 9月27日の区間別ユスリカ観測值と区間気温の関係

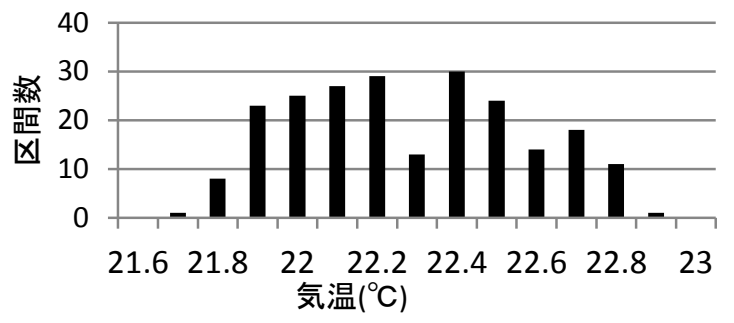

図-16９月27日の全区間気温のヒストグラム

羽化による発生や死による増減については，植生や周辺 建築壁面の調査，河道における羽化後行動の観察，水質 の調査と合わせて議論する必要がある.

\section{参考文献}

1) 村上行啓, 五十嵐隆夫, 佐伯陽子, 足立雄一, 松野正知, 岡田敏夫, 河合幸一郎, 熊谷朗, 佐々学 : ユスリカ喘息に 関する研究. 第 II 報 ユスリカ種別間の交叉抗原性につい て.アレルギー，36,81-85, 1987.

2) 平林公男 : 諏訪湖地域における “迷惑昆虫”ユスリカの大 発生とその防除策 第一報：アカムシュスリカ

(Tokunagayusurika akamusi) 成虫の大量飛来, 日本衛生学 雑誌, 46 (2), $652-661,1991$.

3) 平林公男, 中里亮治, 沖野外輝夫 : 諏訪湖におけるユスリ 力研究 (2)不快昆虫としての成虫とその防除策に関する検 討, 山地水環境教育センター研究報告， 1，53-62， 2003.

4) Kanda, M: Progress in urban meteorology: A Review, Journal of the Meteorological Society of Japan, Vol.85, pp.365-383, 2007.

5) 近藤繁生, 平林公男, 岩熊敏夫, 上野隆平 : ユスリカの世 界，培風館，2001。

6) Kon, M.: Swarming and Mating of Chironomus yoshimatsui (Diptera: Chironomidae): Seasonal Change in the Timing of Swarming and Mating, J. Ethol., Vol.2, pp.37-45, 1984.

(2011. 9. 30受付) 